\title{
PEMBUATAN OLEOKIMIA DARI VIRGIN COCONUT OIL (VCO) MELALUI PROSES FRAKSINASI DAN ESTERIFIKASI
}

\author{
OLEOCHEMICAL MAKING FROM VIRGIN COCONUT OIL (VCO) THROUGH \\ FRACTIONATION AND ESTERIFICATION PROCESS
}

\author{
Anton Muis \\ Balai Riset dan Standardisasi Industri Manado \\ Jalan Diponegoro No. 21-23 Manado \\ Telp. (0431) 852395, Fax. (0431) 852396 \\ Pos-el:muisanton@yahoo.co.id
}

\begin{abstract}
ABSTRAK
Virgin Coconut Oil (VCO) adalah minyak yang dibuat dari buah kelapa segar matang yang diproses secara mekanik atau alamiah dengan atau tanpa pemanasan dan penambahan bahan kimia dan zat aditif, salah satu produk alternatif pengembangan pengolahan VCO adalah oleokimia. Tujuan penelitan ini adalah untuk mengoptimalkan metode fraksinasi/pemisahan asam lemak dengan proses hidrolisis dan transesterifikasi. Penelitian ini dilaksanakan dalam dua tahap yaitu: Penelitian pendahuluan untuk menguji kemurnian asam lemak khususnya asam laurat yang dihasilkan pada penelitian sebelumnya dan melakukan fraksinasi asam lemak dengan menggunakan spinning band fractionation. Penelitian lanjutan dilakukan dengan menfraksinasi asam lemak melalui reaksi esterifikasi dan hidrolisis. Reaksi esterifikasi dilakukan dengan perlakuan jumlah katalis $\mathrm{NaOH}$ yaitu: 0,2 mol dan 0,02 mol dengan waktu reaksi selama 60 menit. Reaksi hidolisis dilakukan dengan perlakuan waktu hidrolisis dan jenis katalis, waktu hidrolisis yang dilakukan adalah 3, 6, 9 dan 12 jam, sedangkan jenis katalis yang gunakan adalah $\mathrm{HCl} 6 \mathrm{~N} 3 \mathrm{ml}$ dan $\mathrm{H}_{2} \mathrm{SO}_{4} 50 \%$ dengan perbandingan 1:20 (katalis:minyak). Hasil penelitian ini dapat diketahui bahwa kemurnian asam lemak pada proses fraksinasi penelitian sebelumnya belum optimal, sehingga masih perlu mengoptimalkan proses fraksinasi untuk memisahkan asam lemak. Reaksi esterifikasi dan hidrolisis yang dilakukan belum memberikan hasil yang optimal, masih perlu mengoptimalkan suhu, tekanan, jumlah dan jenis katalis untuk bisa memutuskan rantai pada molekul trigliserida. Nilai FFA pada penelitian ini masih berada kisaran 2,1-7,2\%, sedangkan spliting degree pada kisaran1,2-2,4\%.

Kata Kunci: Esterifikasi, oleokimia fraksinasi, VCO.
\end{abstract}

\section{ABSTRACT}

Virgin Coconut Oil (VCO) is produced from mature fresh coconuts which are processed mechanically, naturally, with or without heating or by chemicals and additives addition. One of the alternative products for developing VCO processing is oleochemistry. This research aims to optimize hydrolysis and transesterification process as fractionation method of fatty acid. This research was be carried out in two stages, namely: preliminary research to test the purity of fatty acids especially lauric acid that be produced in previous studies and to fractionate fatty acids using a spinning band fractionation. Further research is carried out by fractionating fatty acids through esterification and hydrolysis reactions. The esterification reaction was carried out by treating the amount of $\mathrm{NaOH}$ catalyst namely: $0.2 \mathrm{~mol}$ and $0.02 \mathrm{~mol}$ with a reaction time of 60 minutes. The hydrolysis reaction was carried out by treatment of hydrolysis time and kind of catalyst, the hydrolysis time performed was 3, 6, 9 and 12 hours, while the type of catalyst used was $3 \mathrm{ml} \mathrm{HCl} \mathrm{N}$ and $50 \% \mathrm{H}_{2} \mathrm{SO}_{4}$ with a ratio of 1:20 (catalyst:oil). The results of this study can be seen that the purity of fatty acids in the fractionation process of previous studies is not optimal, so it still needs to optimize the fractionation process to separate fatty acids. Esterification and hydrolysis reactions carried out have not provided optimal results, still need to optimize temperature, pressure, number and type the catalyst can break the chain on the triglyceride molecule. The FFA value in this study is still in the range of $2.1-7.2 \%$, while the spliting degree is in the range of $1.2-2.4 \%$.

Keywords: Esterification, oleochemistry fractionation, VCO.

\section{PENDAHULUAN}

Minyak kelapa termasuk VCO merupakan ester dari gliserol dan asam lemak selain dapat dimanfaatkan sebagai minyak makan juga dapat diolah menjadi senyawa oleokimia. Oleokimia merupakan produk kimia yang berasal dari minyak atau lemak, baik nabati maupun hewani ${ }^{(1)}$. Pembuatan oleokimia dilakukan dengan cara memutus struktur trigliserida dari minyak atau lemak menjadi asam lemak dan gliserin, atau memodifikasi gugus fungsi karboksilat dan hidroksilnya, baik secara kimia, fisika, maupun biologi ${ }^{(2)}$. Oleokimia dibagi menjadi 
dua yaitu oleokimia dasar, dan turunannya atau produk hilirnya. Oleokimia dasar terdiri atas fatty acid, fatty methyl ester, fatty alcohol, fatty amine, dan gliserol. Sedangkan produk-produk turunannya antara lain sabun batangan, deterjen, shampoo, pelembut kosmetik, bahan tambahan untuk industri plastik, karet, dan pelumas.

VCO merupakan salah satu jenis minyak sehingga memiliki komponen penyusun dasar yang sama dengan jenis minyak lainnya yaitu terbentuk dari rantai karbon, hidrogen dan oksigen serta mengandung gugus karboksilat yang disebut asam lemak, komponen asam lemak tersebut membentuk gliserida saat bergabung dengan gliserol $^{(3)}$. Gliserida yang umumnya terdapat pada minyak dan lemak yaitu trigliserida yang akan terbentuk bila tiga asam lemak beresterifikasi dengan satu molekul gliserol yang dikenal dengan trigliserida. Sifat minyak dan lemak dipengaruhi oleh sifat fisik-kimia asam lemaknya $^{(4)}$, khususnya VCO mengandung asam jenuh $\pm 90 \%$ dan $\pm 10 \%$ asam lemak tak jenuh. Asam lemak jenuh pada VCO didominasi oleh asam lemak laurat yaitu sekitar 47-53\%. Asam lemak jenuh pada VCO merupakan asam lemak golongan rantai sedang (MCFA) yaitu asam lemak dengan jumlah rantai atom karbon $\mathrm{C}_{6}-\mathrm{C}_{12}{ }^{(5,6)}$. Hidrolisis sangat mudah terjadi pada golongan lemak yang mengandung asam lemak dengan berat molekul rendah yaitu asam lemak dengan jumlah karbon kurang dari 14 seperti kandungan asam lemak pada minyak kelapa yang didominasi oleh asam lemak rantai sedang ${ }^{(3)}$.

VCO sudah mengalami perkembangan baik dalam hal teknologi pembuatan maupun pemanfaatannya, namun pengembangan VCO menjadi produk turunannya belum banyak dikembangkan. Sejauh ini produk yang dapat dikembangkan dari VCO antara lain produk kosmetik (sabun kesehatan dan krim pelembab) dan ekstrak VCO untuk antioksidan $^{(7,8)}$.

Salah satu alternatif produk pengembangan pengolahan VCO adalah oleokimia. Produk oleokimia yang dikembangkan dari minyak kelapa termasuk VCO adalah senyawa-senyawa asam lemak, alkohol asam lemak, dan gliserin. Dimana senyawa tersebut dapat diolah lebih lanjut menjadi metil ester, alkanolamida, etoksilat. Penelitian ini akan mengoptimalkan proses fraksinasi asam laurat kemudian menguji kemurnian asam laurat hasil fraksinasi pada hasil penelitian sebelumnya. Tujuan penelitan untuk menguji tingkat kemurnian asam laurat dari hasil penelitian sebelumnya dan mengoptimalkan cara fraksinasi/pemisahan asam lemak dengan proses hidrolisis dan transesterifikasi. Ruang lingkup penelitian adalah menguji kemurnian asam lemak khususnya asam laurat hasil esterifikasi pada penelitian sebelumnya dan mengoptimalkan proses fraksinasi melalui reaksi esterifikasi/transesterifikasi dan hidrolisis.

\section{BAHAN DAN METODE}

\section{Bahan dan Alat}

Bahan baku yang digunakan dalam penelitian ini yaitu VCO dan bahan pendukung lainnya. Peralatan yang digunakan yaitu $\mathrm{pH}$ meter, alat destilasi, vakum evaporator, timbangan analitik, pemanas listrik dilengkapi dengan magnetic 
stirrer, GC serta peralatan gelas lain yang diperlukan untuk analisis kimia.

\section{Metode Penelitian}

Penelitian ini akan dilaksanakan dalam dua tahap yaitu:

1. Penelitian pendahuluan untuk menguji kemurnian asam lemak khususnya asam laurat yang dihasilkan pada penelitian sebelumnya dan melakukan fraksinasi asam lemak dengan menggunakan alat spinning band fractionation. Pada penelitian pendahuluan juga dilakukan fraksinasi asam lemak dari VCO berdasarkan titik leleh, dimana minyak dibekukan kemudian cairkan kembali dan dilakukan pemisahan antara fraksi cair dengan fraksi padat.

2. Melakukan fraksinasi asam lemak melalui reaksi esterifikasi dan hidrolisis. Reaksi esterifikasi dilakukan dengan perlakuan jumlah katalis $\mathrm{NaOH}$ yaitu: $0,2 \mathrm{~mol}$ dan 0,02 mol dengan waktu reaksi selama 60 menit. Reaksi hidolisis dilakukan dengan perlakuan waktu hidrolisis dan jenis katalis, waktu hidrolisis yang dilakukan adalah 3, 6, 9 dan 12 jam, sedangkan jenis katalis yang digunakan adalah $\mathrm{HCl} 6$ $\mathrm{N} 3 \mathrm{ml}$ dan $\mathrm{H}_{2} \mathrm{SO}_{4} \quad 50 \%$ dengan perbandingan 1:20 (katalis:minyak)

\section{Prosedur Penelitian}

\section{Fraksinasi Asam Lemak (Laurat)}

a. Timbang VCO sebanyak $100 \mathrm{~g}$ kedalam erlenmeyer 1 liter. Tambahkan metanol sebanyak $120 \mathrm{ml}$, kemudian tambahkan juga $1 \mathrm{~g}$ natrium sulfat.

b. Atur pHnya sampai pada $\mathrm{pH}$ 7. Direfluks selama 2 jam pada suhu $70-80^{\circ} \mathrm{C}$ menggunakan pemanas yang dilengkapi dengan pengaduk magnetic stirrer. c. Selanjutnya didinginkan, kemudian campuran larutan dimasukkan ke dalam labu pisah yang telah berisi aquades sebanyak $100 \mathrm{ml}$, dan dikocok.

d. Tambahkan $10 \mathrm{ml}$ asam sulfat $6 \mathrm{~N}$, kemudian dikocok lagi.

e. Tambahkan lagi $12 \mathrm{ml}$ asam sulfat $6 \mathrm{~N}$ dalam $68 \mathrm{ml}$ aquades, larutan dikocok, kemudian diatur pHnya hingga mencapai $\mathrm{pH} 3$, selanjutnya pisahkan.

f. Lapisan bawah diekstraksi dengan eter pada suhu kamar selama \pm 10 menit. Kemudian lapisan bagian bawah ditampung dalam erlenmeyer, lapisan atas (eter) dicuci dengan air suling $20 \mathrm{ml}$ sebanyak 3 kali, hasil cucian (lapisan bawah) dicampur dengan hasil ekstraksi dalam erlenmeyer.

g. Hasil ekstraksi ditambahkan natrium sulfat anhidrat, kemudian didiamkan selama \pm 24 jam .

h. Disaring kemudian didestilasi sampai terbentuk Kristal putih dalam labu destilasi. Asam laurat yang diperoleh dikeringkan, kemudian ditimbang.

\section{Esterifikasi/ Transesterifikasi Minyak}

Sebanyak 200 g VCO ditambahkan $100 \mathrm{~g}$ etanol dan katalis $\mathrm{NaOH}$ (sesuai perlakuan), kemudian dicampurkan sambil diaduk selama 1 jam dengan menggunakan magnetic stirrer pada suhu ruang. Setelah reaksi selesai ditambahkan $\mathrm{HCl} 6 \mathrm{~N}$ sampai mencapai $\mathrm{pH} 3$ sehingga terjadi dua lapisan yaitu air-alkohol dan minyak, selanjutnya dipisahkan dengan menggunakan labu pisah. Minyak yang sudah terpisah ditambahkan natrium sulfat anhidrat untuk mengeluarkan kandungan air yang masih tersisa. selanjutnya dilakukan pengujian FFA 
dan fraksinasi asam lemak dengan menggunakan vakum evaporator.

\section{Hidrolisis Asam Minyak}

Sebanyak 200 ml VCO ditambahkan katalis sesuai dengan perlakuan $(\mathrm{HCl} 1 \mathrm{~N} 3$ $\mathrm{ml}, \mathrm{H}_{2} \mathrm{SO}_{4} 50 \% 20 \mathrm{ml}$ ), kemudian dipanaskan dengan sistem refluks pada suhu $110^{\circ} \mathrm{C}$ dengan waktu sesuai perlakukan (3, 6, 9 dan 12 jam). Setelah proses reaksi selesai kemudian didiamkan untuk proses pendinginan dan pemisahan air dan minyak. Proses pemisahan menggunakan labu pisah, kemudian dilakukan pengujian FFA dan bilangan penyabunan, selanjutnya dilakukan proses fraksinasi dengan menggunakan vakum epavorator.

\section{Pengamatan}

Parameter yang diamati yaitu kemurnian asam laurat, medium chain fatty acid dengan menggunakan GC, FFA, bilangan penyabunan dan splitting degree (SD).

\section{HASIL DAN PEMBAHASAN}

Proses fraksinasi dilakukan pada kondisi suhu proses $250^{\circ} \mathrm{C}$ dan tekanan 16 psi (kondisi optimal alat) namun pada kondisi proses tersebut belum terjadi proses pemisahan asam lemak. Padahal berdasarkan literatur titik didih asam laurat $\left(\mathrm{C}_{12}\right)$ adalah $225^{\circ} \mathrm{C}$, sehingga pada kondisi suhu proses yang dilakukan pada penelitian pendahuluan seharusnya asam lemak dari $\mathrm{C}_{6}-\mathrm{C}_{12}$ sudah dapat terpisah. Hal ini diakibatkan bahwa proses fraksinasi asam lemak dari minyak secara fisika tidak bisa lakukan apabila asam lemak tersebut masih dalam molekul trigliserida, sehingga untuk melakukan fraksinasi asam lemak maka ikatan karbon antara molekul asam lemak dengan gliserol harus diputuskan terlebih dahulu atau molekul asam lemak tersebut sudah dalam bentuk metil ester asam lemak ${ }^{(9)}$. Pemutusan rantai trigliserida dapat dilakukan melalui reaksi hidrolisis dan esterifikasi/transesterifikasi, sehingga pada tahapan penelitian berikutnya akan mengoptimalkan pemutusan ikatan karbon asam lemak dari rantai trigliserida, selanjutnya dilakukan proses fraksinasi ${ }^{(9)}$.

\section{Pengujian kemurnian Asam Laurat}

Penelitian ini merupakan penelitian pengembangan dari tahun sebelumnya dengan tujuan untuk mengoptimalkan proses pemisahan asam lemak khususnya asam laurat, sehingga pada penelitian ini juga menguji kemurnian asam lemak yang didapatkan pada penelitian sebelumnya untuk mengetahui tingkat kemurnian substrat yang dihasilkan. Pengujian kemurnian asam lemak dilakukan dengan menggunakan alat Gas Chromatography (GC). Hasil pengujian kemurnian asam lemak dapat dilihat pada Tabel 1 dan Gambar 1. Pada Tabel 1 dapat dilihat bahwa terjadi perbedaan komposisi asam lemak VCO sebelum dan setelah fraksinasi. Pada proses fraksinasi penelitian sebelumnya, sasaran yang diharapkan adalah dipisahkannya atau dimurnikannya asam-asam lemak khususnya asam laurat dari asam-asam lemak lainnya yang ada di dalam VCO, tetapi asam laurat yang dihasilkan berdasarkan hasil pengujian dengan menggunakan GC jumlahnya menurun menjadi 28,51\%, padahal yang diharapkan adalah lebih besar dari kandungan asam laurat sebelum fraksinasi

yaitu

$47,03 \%$. 
Tabel 1. Komposisi asam lemak VCO sebelum dan setelah fraksinasi

\begin{tabular}{cllcc}
\hline No. & Asam Lemak & Formula & $\begin{array}{c}\text { Sebelum } \\
\text { Fraksinasi (\%) }\end{array}$ & $\begin{array}{c}\text { Setelah } \\
\text { Fraksinasi (\%) }\end{array}$ \\
\hline 1 & Kaporat & $\mathrm{C}_{6} \mathrm{H}_{12} \mathrm{O}_{2}$ & 0,47 & 4,68 \\
2 & Kaprilat & $\mathrm{C}_{8} \mathrm{H}_{16} \mathrm{O}_{2}$ & 6,56 & 4,82 \\
3 & Kaprat & $\mathrm{C}_{10} \mathrm{H}_{20} \mathrm{O}_{2}$ & 5,55 & 6,06 \\
4 & Laurat & $\mathrm{C}_{12} \mathrm{H}_{24} \mathrm{O}_{2}$ & 47,03 & 28,51 \\
5 & Miristat & $\mathrm{C}_{14} \mathrm{H}_{28} \mathrm{O}_{2}$ & 19,98 & 6,88 \\
6 & Palmitat & $\mathrm{C}_{16} \mathrm{H}_{32} \mathrm{O}_{2}$ & 10,00 & 0,72 \\
7 & Palmitoleat & $\mathrm{C}_{16} \mathrm{H}_{31} \mathrm{O}_{2}$ & - & 6,72 \\
8 & Stearat & $\mathrm{C}_{18} \mathrm{H}_{36} \mathrm{O}_{2}$ & 3,08 & 15,12 \\
9 & Oleat & $\mathrm{C}_{18} \mathrm{H}_{34} \mathrm{O}_{2}$ & 5,99 & 10,3 \\
10 & Linoleat & $\mathrm{C}_{18} \mathrm{H}_{32} \mathrm{O}_{2}$ & 1,36 & 5,45 \\
11 & Alfa-Linoleat & $\mathrm{C}_{18} \mathrm{H}_{31} \mathrm{O}_{2}$ & - & 1,59 \\
12 & Arakidat & $\mathrm{C}_{20} \mathrm{H}_{40} \mathrm{O}_{2}$ & - & 8,27 \\
\hline
\end{tabular}

Hal ini mengindikasikan bahwa proses fraksinasi untuk memisahkan asam laurat belum optimal. Pada Tabel 1 juga dapat dilihat bahwa beberapa asam lemak yang mengalami peningkatan bobot seperti: kaproat, kaprat, stearat, oleat dan linoleat selain itu juga terdapat asam-asam lemak yang mengalami penurunan bobot seperti: kaprilat, laurat dan miristat. Pada Tabel 1 juga dapat lihat bahwa terdeteksi kandungan asam lemak baru setelah proses fraksinasi yang sebelumnya tidak ada seperti: asam lemak palmitoleat $\left(\mathrm{C}_{16} \mathrm{H}_{31} \mathrm{O}_{2}\right)$, alfa-linolenat $\left(\mathrm{C}_{18} \mathrm{H}_{31} \mathrm{O}_{2}\right)$ dan arakidat $\left(\mathrm{C}_{20} \mathrm{H}_{40} \mathrm{O}_{2}\right)$. Terbentuknya senyawa asam lemak baru tersebut diduga karena prosedur fraksinasi yang digunakan adalah reaksi transesterifikasi sehingga sangat memungkinkan terjadinya reaksi adisi dan eliminasi pada gugus atom dan ikatan rangkap (ikatan tak jenuh) dari asam lemak.
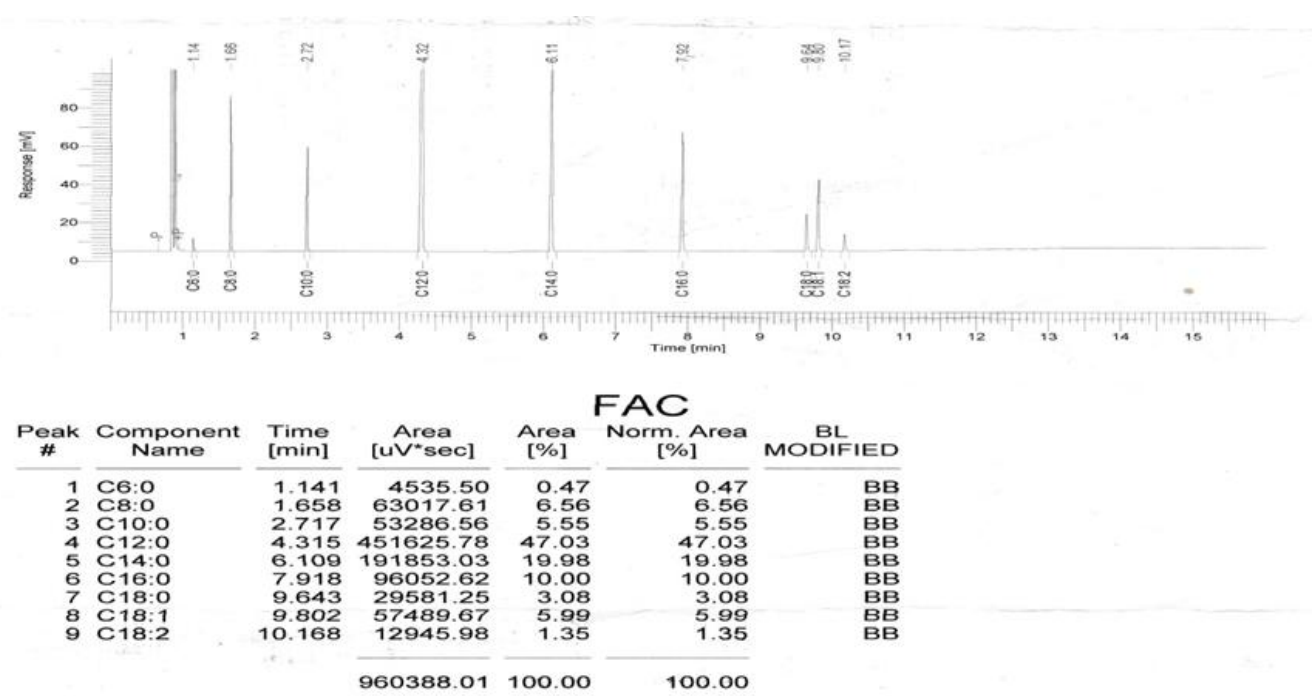

Gambar 1. Kromatogram asam lemak VCO sebelum dan setelah fraksinasi

Pada penelitian pendahuluan juga dilakukan pemisahan asam lemak berdasarkan titik leleh, dimana minyak dibekukan terlebih dahulu kemudian 
dilelehkan, fraksi yang mengalami proses pelelehan terlebih dahulu kemudian dipisahkan dari fraksi yang padat dan diuji menggunakan GC. Kandungan asam lemak hasil pengujian berdasarkan titik leleh dapat dilihat pada Tabel 2 dan Gambar 2.

Pada Tabel 2 dapat dilihat bahwa kandungan asam lemak hasil pemisahan berdasarkan titik leleh cenderung hampir sama, komposisi dan kuantitasnya memiliki perbedaan yang tidak signifikan kecuali asam lemak miristat pada saat beku sekitar $10,18 \%$ kemudian setelah mencair sekitar $19,21 \%$. Proses ini juga tidak berjalan optimal karena yang diharapkan adalah terjadi proses pemisahan antara rantai sedang dan panjang, sehingga dengan metode pemisahan berdasarkan titik leleh diharapkan fraksi cair komposisinya mengandung sejumlah besar asam lemak rantai sedang $\left(\mathrm{C}_{6}-\mathrm{C}_{12}\right)$. Begitupun juga untuk fraksi padat diharapkan hanya mengandung asam lemak rantai panjang $\left(\mathrm{C}_{14}-\mathrm{C}_{18)}\right.$

Pada Tabel 2 juga dapat dilihat bahwa terdapat kandungan asam lemak lain yang terdeteksi setelah proses pembekuan yaitu $\mathrm{C}_{13: 0}$ sekitar $0,03 \%$.

Tabel 2. Komposisi asam lemak VCO berdasarkan titik leleh

\begin{tabular}{clccc}
\hline No & Asam Lemak & Formula & Cair (\%) & Beku (\%) \\
\hline 1 & Kaproat & $\mathrm{C}_{6} \mathrm{H}_{12} \mathrm{O}_{2}$ & 0,57 & 0,57 \\
2 & Kaprilat & $\mathrm{C}_{8} \mathrm{H}_{16} \mathrm{O}_{2}$ & 7,20 & 7,18 \\
3 & Kaprat & $\mathrm{C}_{10} \mathrm{H}_{20} \mathrm{O}_{2}$ & 5,68 & 5,68 \\
4 & Laurat & $\mathrm{C}_{12} \mathrm{H}_{24} \mathrm{O}_{2}$ & 46,12 & 46,12 \\
5 & & $\mathrm{C}_{13} \mathrm{H}_{26} \mathrm{O}_{2}$ & 0,03 & - \\
6 & Miristat & $\mathrm{C}_{14} \mathrm{H}_{28} \mathrm{O}_{2}$ & 19,21 & 10,18 \\
7 & Palmitat & $\mathrm{C}_{16} \mathrm{H}_{32} \mathrm{O}_{2}$ & 9,85 & 9,89 \\
8 & Stearat & $\mathrm{C}_{18} \mathrm{H}_{36} \mathrm{O}_{2}$ & 3,19 & 3,23 \\
9 & Oleat & $\mathrm{C}_{18} \mathrm{H}_{34} \mathrm{O}_{2}$ & 6,45 & 6,52 \\
10 & Linoleat & $\mathrm{C}_{18} \mathrm{H}_{32} \mathrm{O}_{2}$ & 1,48 & 1,48 \\
11 & Arakidat & $\mathrm{C}_{20} \mathrm{H}_{40} \mathrm{O}_{2}$ & 0,09 & 0,09 \\
12 & & & 0,04 & 0,04 \\
\hline
\end{tabular}

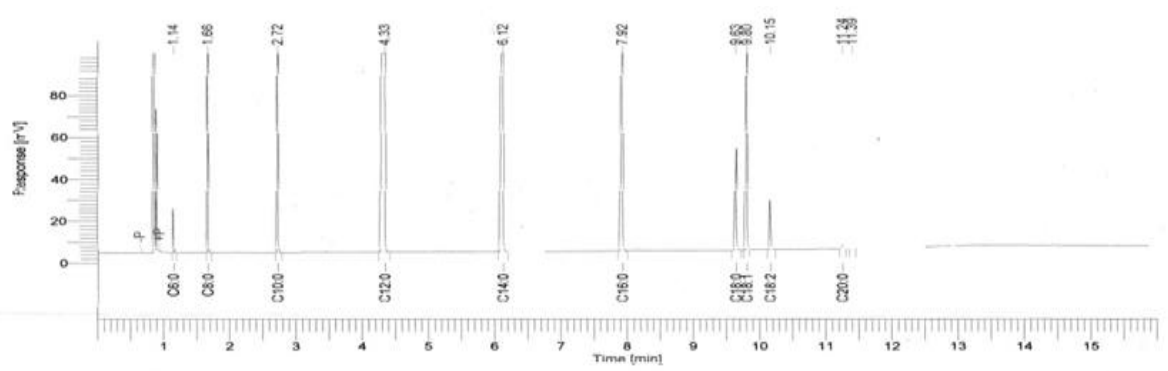

FAC

\begin{tabular}{|c|c|c|c|c|c|c|}
\hline$\underset{\#}{\text { Peak }}$ & $\begin{array}{c}\text { Component } \\
\text { Name }\end{array}$ & $\begin{array}{l}\text { Time } \\
\text { [min! }\end{array}$ & $\begin{array}{c}\text { Area } \\
{\left[u V^{*} \text { sec] }\right.}\end{array}$ & $\begin{array}{l}\text { Area } \\
{[\%]}\end{array}$ & $\begin{array}{c}\text { Norm. Area } \\
{[\%]}\end{array}$ & $\begin{array}{c}\text { BL } \\
\text { MODIFIED }\end{array}$ \\
\hline 1 & C6:0 & 1.143 & 13791.30 & 0.57 & 0.57 & BB \\
\hline 2 & C8:0 & 1.660 & 173735.56 & 7.18 & 7.18 & BB \\
\hline 3 & C10:0 & 2.717 & 137517.11 & 5.68 & 5.68 & BB \\
\hline 4 & C12:0 & 4.334 & 1115933.83 & 46.12 & 46.12 & BB \\
\hline 5 & C14:0 & 6.118 & 484008.38 & 10.18 & 10.18 & $\mathrm{Ee}$ \\
\hline 6 & C16:0 & 7.919 & 239246.97 & 9.89 & 9.89 & $\mathrm{BB}$ \\
\hline & C18:0 & 9.634 & 78154.03 & 3.23 & 3.23 & BB \\
\hline & Cis.1 & 9.799 & 157796.34 & 6.52 & 6.52 & 政 \\
\hline $\begin{array}{l}\circ \\
9\end{array}$ & C18:2 & 10.153 & 36162.34 & 1.49 & 1.49 & BB \\
\hline 10 & C20:0 & 11.242 & 2158.47 & 0.09 & 0.09 & $\mathrm{BB}$ \\
\hline \multirow[t]{2}{*}{71} & & 11.391 & 1013.17 & 0.04 & 0.04 & BB \\
\hline & & & 2418517.50 & 00.00 & 100.00 & \\
\hline
\end{tabular}

Gambar 2. Kromatogram fraksinasi asam lemak VCO berdasarkan titik leleh 
Fraksinasi Asam Lemak VCO dengan Reaksi esterifikasi

Reaksi esterifikasi pada proses fraksinasi asam lemak bertujuan untuk memutuskan ikatan asam lemak dengan gliserol yang membentuk trigliserida. Reaksi esterifikasi dilakukan dengan mereaksikan minyak dan alkohol (etanol) menggunakan bantuan katalis $\mathrm{NaOH}$ dengan tujuan untuk memutuskan rantai trigliserida pada minyak menjadi asam lemak dan gliserol $^{(10)}$.

Untuk menguji reaksi esterifikasi berjalan optimal dapat dilakukan dengan pengujian bilangan asam (FFA) atau dengan menggunakan alat GC untuk menentukan jumlah kandungan asam-asam lemak yang ada. Kadar FFA minyak hasil reaksi esterifikasi dengan perlakukan jumlah mol $\mathrm{NaOH}$ sebagai berikut: perlakuan katalis $0,2 \mathrm{~mol}$ adalah 7,23\% sedangkan perlakuan katalis $\mathrm{NaOH} 0,02$ mol adalah $1,22 \%$. Dari hasil pengujian FFA dapat dilihat bahwa dengan jumlah katalis yang lebih besar memiliki nilai FFA yang lebih tinggi, namun dari hasil penelitian ini belum memberikan hasil yang optimal sesuai yang diharapkan. Hasil yang diharapkan adalah kandungan FFA setelah akhir proses bisa mencapai $60 \%$ dengan tujuan bahwa ikatan karbon asam lemak rantai sedang $\left(\mathrm{C}_{6}-\mathrm{C}_{12}\right)$ sebagian besar sudah terputus dan sudah dalam bentuk metil ester asam lemak.

Tabel 3. Komposisi asam lemak VCO berdasarkan jumlah katalis $\mathrm{NaOH}$

\begin{tabular}{|c|c|c|c|c|c|}
\hline No. & Asam Lemak & Formula & $0,2 \mathrm{~mol}(\%)$ & $0,02 \mathrm{~mol}(\%)$ & $\begin{array}{c}0,02 \mathrm{~mol} \\
\text { (beku) (\%) }\end{array}$ \\
\hline 1 & & & 0,39 & - & - \\
\hline 2 & & & 0,21 & - & - \\
\hline 3 & Kaproat & $\mathrm{C}_{6} \mathrm{H}_{12} \mathrm{O}_{2}$ & 0,43 & 0,45 & 0,44 \\
\hline 4 & Kaprilat & $\mathrm{C}_{8} \mathrm{H}_{16} \mathrm{O}_{2}$ & 5,75 & 6,18 & 6,21 \\
\hline 5 & & & 1,05 & 0,19 & 0,17 \\
\hline 6 & & & 0,52 & - & - \\
\hline 7 & & & 1,04 & - & - \\
\hline 8 & Kaprat & $\mathrm{C}_{10} \mathrm{H}_{20} \mathrm{O}_{2}$ & 5,11 & 5,24 & 5,28 \\
\hline 9 & & & 0,23 & 0,16 & 0,15 \\
\hline 10 & Laurat & $\mathrm{C}_{12} \mathrm{H}_{24} \mathrm{O}_{2}$ & 41,76 & 44,78 & 45,15 \\
\hline 11 & & & 1,18 & 1,32 & 1,24 \\
\hline 12 & & & 0,15 & - & - \\
\hline 13 & Miristat & $\mathrm{C}_{14} \mathrm{H}_{28} \mathrm{O}_{2}$ & 17,84 & 19,29 & 19,43 \\
\hline 14 & & & 0,80 & 0,61 & 0,59 \\
\hline 15 & & $\mathrm{C}_{15} \mathrm{H}_{30} \mathrm{O}_{2}$ & & 0,36 & - \\
\hline 16 & Palmitat & $\mathrm{C}_{16} \mathrm{H}_{32} \mathrm{O}_{2}$ & 9,23 & 9,98 & 10,01 \\
\hline 17 & & $\mathrm{C}_{16} \mathrm{H}_{31} \mathrm{O}_{2}$ & 0,33 & 0,33 & 0,32 \\
\hline 18 & & $\mathrm{C}_{17} \mathrm{H}_{34} \mathrm{O}_{2}$ & 0,49 & - & - \\
\hline 19 & Stearat & $\mathrm{C}_{18} \mathrm{H}_{36} \mathrm{O}_{2}$ & 3,02 & 3,26 & 3,25 \\
\hline 20 & Oleat & $\mathrm{C}_{18} \mathrm{H}_{34} \mathrm{O}_{2}$ & 5,72 & 6,16 & 6,18 \\
\hline 21 & & & 0,19 & 0,11 & 0,19 \\
\hline 22 & & & - & 0,20 & - \\
\hline 23 & Linoleat & $\mathrm{C}_{18} \mathrm{H}_{32} \mathrm{O}_{2}$ & 1,29 & 1,38 & 1,39 \\
\hline 24 & & & 2,06 & - & - \\
\hline 25 & & & 0,89 & - & - \\
\hline 26 & & & 0,30 & - & - \\
\hline
\end{tabular}


Fraksinasi Asam Lemak VCO dengan Reaksi Hidrolisis

Reaksi hidrolisis pada proses fraksinasi asam lemak bertujuan untuk memutuskan ikatan asam lemak dengan gliserol yang membentuk trigliserida. Reaksi hidrolisis dilakukan dengan mereaksikan minyak dengan air pada kondisi suhu tinggi dengan bantuan katalis $^{(11)}$. Penggunaan katalis dalam reaksi hidolisis bertujuan untuk menurunkan energi aktivasi dari ikatan asam lemak dengan molekul gliserol $^{(10)}$.

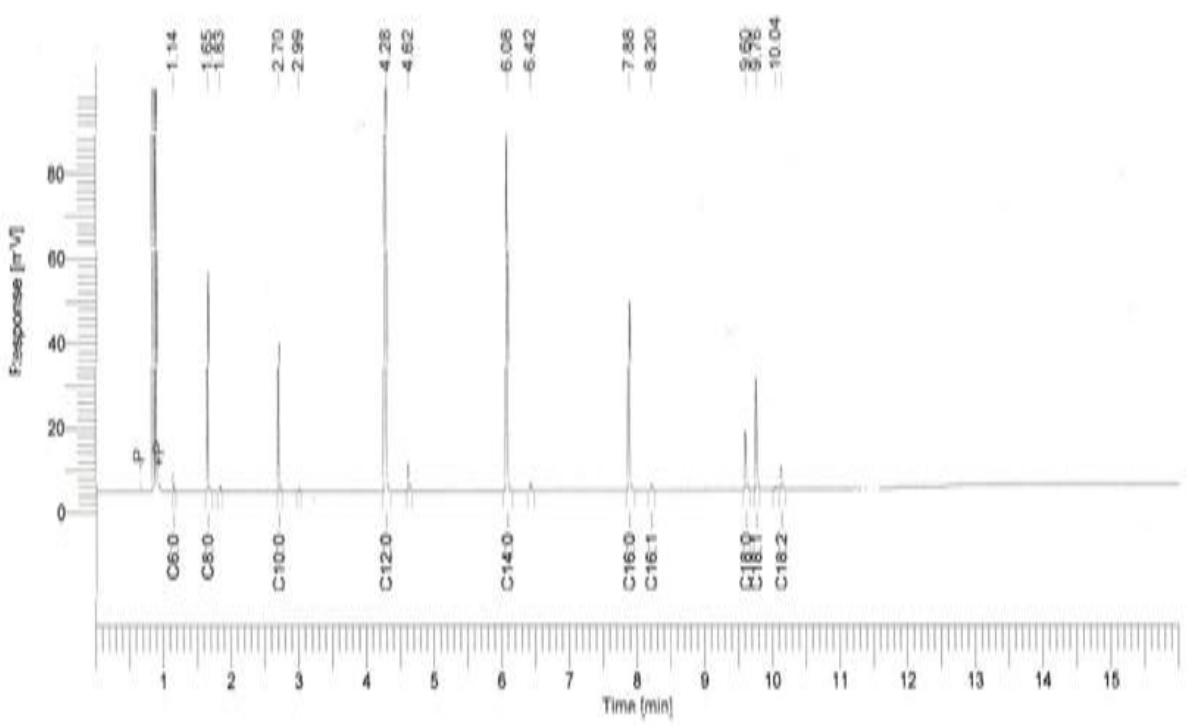

FAC

\begin{tabular}{|c|c|c|c|c|c|}
\hline $\begin{array}{c}\text { Peak Component } \\
\# \quad \text { Name }\end{array}$ & $\begin{array}{l}\text { Time } \\
\text { [min! }\end{array}$ & $\begin{array}{c}\text { Area } \\
\text { [uV"sec] }\end{array}$ & $\begin{array}{l}\text { Area } \\
{[\% !}\end{array}$ & $\begin{array}{c}\text { Norm. Area } \\
{[\%]}\end{array}$ & $\begin{array}{c}\text { BL } \\
\text { MODIFIED }\end{array}$ \\
\hline $1 \mathrm{C} 6: 0$ & 1.139 & 2846.87 & 0.44 & 0.44 & BB \\
\hline $2 \mathrm{C} 8: 0$ & 1.651 & 39977.40 & 6.21 & 6.2 & \\
\hline 3 & 1.827 & 1088.14 & 0.17 & 0.17 & B \\
\hline $4 \mathrm{C} 10: 0$ & 2.701 & 34004.88 & 5.28 & 5.28 & BB \\
\hline 5 & 2.001 & 084.02 & 0.15 & 0.15 & 38 \\
\hline $6 \mathrm{C} 12: 0$ & 4.285 & 290792.28 & 45.15 & 45.15 & Do \\
\hline 7 & 4.615 & 7960.90 & 1.24 & 1.24 & \\
\hline $8 \mathrm{Ci4.0}$ & 6.075 & 125149.36 & 10.43 & 19.43 & 60 \\
\hline$\theta$ & 6.416 & 3770.90 & 0.59 & 0.59 & \\
\hline $10 \mathrm{C} 16: 0$ & 7.879 & 64484.81 & 10.01 & 10.01 & \\
\hline $11 \mathrm{C} 16: 1$ & 8.202 & 2056,68 & 0.32 & 0.32 & Do \\
\hline $12 \mathrm{C} 18: 0$ & 9.602 & 20962.15 & 3.2 & 3.2 & \\
\hline $13 \mathrm{C} 18: 1$ & 9.759 & 39809.32 & 6.18 & 6.18 & \\
\hline 14 & 10.042 & 1231.52 & 0.19 & 0.19 & BV \\
\hline $15 \mathrm{C} 18: 2$ & 10.126 & 8934.33 & 1.39 & 1.39 & VB \\
\hline
\end{tabular}

Gambar 3. Kromatogram asam lemak VCO berdasarkan jumlah katalis $\mathrm{NaOH}$ 
Untuk menguji reaksi esterifikasi berjalan optimal juga dapat dilakukan dengan menguji bilangan asam (FFA) dan bilangan penyabunan. Bilangan FFA mengindikasikan bahwa telah terjadi pemutusan ikatan karbon molekul asam lemak dengan molekul gliserol, sehingga semakin tinggi bilangan FFA menunjukkan bahwa semakin banyak kandungan asam lemnak yang terpisah/terputus ikatannya dari gliserol. Sedangkan bilangan penyabunan bertujuan untuk melihat derajat hidrolisis dari suatu reaksi, atau tingkat optimalisasi reaksi hidrolisis yang terjadi $^{(12,13)}$. Kadar FFA dan bilangan penyabunan dapat dilihat pada Tabel 4.

Tabel 4. Kadar FFA, bilangan penyabunan dan splitting degree (SD) VCO setelah reaksi hidrolisis

\begin{tabular}{cccc}
\hline Waktu Hidrolisis (jam) & FFA (\%) & $\begin{array}{c}\text { Bil. Penyabunan } \\
\text { (\%) }\end{array}$ & $\begin{array}{c}\text { Splitting Degree } \\
\text { (SD) (\%) }\end{array}$ \\
\hline Katalis HCL 6N 3ml & & & \\
\hline 0 & 2,18 & 251,50 & 0,8 \\
3 & 2,19 & 249,28 & 0,4 \\
6 & 2,25 & 248,57 & 0,9 \\
9 & 2,45 & 239,81 & 1,02 \\
12 & 2,71 & 259,20 & 1,05 \\
\hline Katalis $\mathrm{H}_{2} \mathrm{SO}_{4} 50 \%(1: 20)$ & & & \\
\hline 12 & 3,24 & 270,32 & 1,2 \\
\hline
\end{tabular}

Dari Tabel 4 dapat dilihat bahwa kadar FFA VCO dari reaksi hidrolisis yang dilakukan pada penelitian ini masih berada pada kisaran 2,18-3,24\% sampai pada waktu reaksi 12 jam untuk kedua jenis katalis yang digunakan, sedangkan spliting degree (SD) masih berada pada nilai 0,8$1,2 \%$. Kandungan FFA dan SD tersebut belum optimal sebagaimana yang diharapkan, karena yang pada proses ini adalah kandungan FFA substrat bisa mencapai $30-50 \%$, sehingga asam lemak rantai sedang sebagian besar sudah terputus ikatannya dan dapat dipisahkan dari asam lemak yang lain (asam lemak rantai panjang). Rendahnya kandungan FFA tersebut kemungkinan disebabkan oleh beberapa faktor diantaranya: suhu hidrolisis belum mencapai kondisi optimal untuk bisa memutuskan ikatan antara asam lemak dengan gliserol, jumlah katalis masih perlu ditingkatkan untuk bisa menurunkan energi aktivasi dalam pemutusan ikatan kimia pada molekul trigliserida, serta diperlukan peralatan yang bisa mengontrol kondisi lingkungan pada proses hidrolisa terutama faktor tekanan dan suhu.

\section{KESIMPULAN DAN SARAN}

\section{KESIMPULAN}

Kemurnian asam lemak pada proses fraksinasi penelitian sebelumnya belum optimal, sehingga masih perlu mengoptimalkan proses fraksinasi untuk memisahkan asam lemak. Nilai FFA dari hidrolisis pada penelitian ini masih berada kisaran 2,1-7,2\%, sedangkan splitting degree pada kisaran 1,2-2,4\%. Hasil Fraksinasi asam lemak dari VCO berdasarkan titik leleh menunjukkan komposisi asam lemak yang cenderung sama antara fraksi padat dan fraksi cair. 
SARAN

Berdasarkan penelitian ini disarankan untuk dapat dilakukan penelitian lanjutan untuk mengoptimalkan suhu, tekanan, jumlah dan jenis katalis pada proses fraksinasi dengan metode reaksi esterifikasi dan hidrolisis untuk bisa memutuskan rantai asam lemak pada molekul trigliserida.

\section{DAFTAR PUSTAKA}

1. Mustofa HK. Strategi pengembangan industri kimia berbasis kelapa di Indonesia [Tesis]. Bogor: Program of Management and Business Institut Pertanian Bogor. 2003.

2. Rumokoi MM, Joseph GH, Rindengan $B$ dan Kembuan $\mathrm{H}$. Pemisahan asam lemak dari minyak kelapa secara enzimatis [Laporan Tahunan]. Balai penelitian Tanaman kelapa dan Palma Lain. Manado. 1996.

3. Winarno FG. Kimia Pangan dan Gizi. PT Gramedia Pustaka Utama. Jakarta. 1995.

4. Ketaren S. Pengantar Teknologi Minyak dan Lemak Pangan. UI Press. Jakarta. 1986.

5. Bruce Fife CNND. Coconut Oil Miracle. PT Bhuana IImu Populer Kelompok Gramedia. Jakarta. 2004.

6. Kabara YE. Health oil from the tree of life; nutritional and health aspects of coconut
Oil [internet].2005. http://www.coconutconnections.com/research

7. Muis A. Pengembangan ekstrak minor virgin coconut oil sebagai pangan fungsional [Komunikasi]. Baristand Industri Manado. 2014.

8. Muis A. Aktivitas antioksidan dan antifotooksidan komponen minor virgin coconut oil [Tesis]. Program Pasca Sarjana Universitas Samratulangi Manado. 2007.

9. Arbianti R, Utami TS, Hermansyah $\mathrm{H}$, Setiawati I dan Rini EL. Transesterifikasi parsial minyak kelapa sawit dengan etanol pada pembuatan digliserida sebagai agen pengemulsi. J Teknik Kimia Indonesia. 2009; 8:33-7

10. Sihotang $H$, Ginting M. Pembuatan monogliserida melalui gliserolisis minyak inti sawit mengunakan katalis natrium metoksida. J Science Kimia 2006; 10(2):51-57

11. Jusman BS, Triyono, Syoufian A. Fractionation of medium chain fatty acid ethyl ester from virgin cococnut oil via transesterification dan destilation under reduced pressure. International $\mathrm{J}$ of Basic Science IJBA_IJENS. 2013; 13(1)

12. Ritonga YM. Pengaruh bilangan asam terhadap hidrolisa minyak kelapa sawit. Digital Library USU. Medan. 2004

13. Darnoko D, Munir C. Kinetics of palm oil transesterification in a batch reactor, university of illinois, department of food science and human nutrition. Agricultural Bioprocess Laboratory; Urbdna Illinois 61801; 2002. 